\title{
Nutrient intakes of different social-class groups: results from the Scottish Heart Health Study (SHHS)
}

\author{
BY C. BOLTON-SMITH, W. C. S. SMITH, M. WOODWAR D* \\ AND H. TUNST ALL-PEDOE \\ Cardiovascular Epidemiology Unit, Ninewells Hospital and Medical School, Dundee DDI 9SY
}

(Received 28 February 1990-Accepted 18 October 1990)

\begin{abstract}
Food frequency questionnaire and socio-demographic data were collected from over 10000 Scottish men and women aged 40-59 years in a cross-sectional study of coronary heart disease (CHD) risk factors. Dietary intake, including the antioxidant vitamins $C$ and $E$ and $\beta$-carotene, was assessed for different socio-economic groups. Trends in nutrient intakes were found with social-class (occupational) groups I-V. The non-manual-manual distinctions were clear even after standardizing for serum cotinine, and alternative classification by housing tenure and level of education did not confound the social-class effect. Total energy intake was significantly higher in the manual (men $10363 \mathrm{KJ}$, women $7507 \mathrm{KJ}$ ) than in the non-manual (men $9156 \mathrm{KJ}$, \%omen $7169 \mathrm{KJ}$ ) groups, and all nutrient amounts except for vitamin $\mathrm{C}$, vitamin $\mathbf{E}, \boldsymbol{\beta}$-carotene and fibie were significantly higher in the manual than the non-manual groups. Alcohol intake was lower in manual women, but higher in manual men compared with their respective non-manual groups. Sex and social-class differences were maintained after adjusting for total energy. Women in general, and manual women in particular, had the highest percentage energy from total fat (40.2) and saturated fat (18.2), while the percentage energy from polyunsaturated fat was lower in men than women, and lowest in manual men (4.4). The polyunsaturated:saturated fat $(P: S)$ ratios were, for non-manual and manual men 0.32 and 0.31 , and for non-manual and manual women 0.31 and 0.28 . Fibre and antioxidant vitamin intakes, when expressed as nutrient densities, were lower in men than women, and lowest in manual men. Overall, men and women in manual occupations had a poorer-quality diet than did those in non-manual occupations. The coincident low $P: S$ ratios and low antioxidant vitamin intakes in manual groups may contribute to an increased risk of CHD. Thus, the findings are compatible with the view that poor diet may be a contributory factor to the higher mortality rates for CHD which occur in the lower socio-economic groups.
\end{abstract}

Nutrient intake: Social class: CHD risk

For at least the last two decades, mortality rates for coronary heart disease (CHD) in Scotland and Northern Ireland have been amongst the highest in the world, and levels in England and Wales are little better (Tunstall-Pedoe et al. 1986; Uemura \& Pisa, 1988). This applies to both men and women, and while CHD mortality rates are still higher in men, there is evidence that the difference between the sexes is decreasing due to a slower relative decline in CHD mortality in women than men (Uemura \& Pisa, 1988). This sex differential is especially evident in the lower social-class groups which also have the highest mortality rates and a lower rate of decline in CHD mortality compared with non-manual professions (Heller et al. 1984; Marmot \& McDowall, 1986; Inequalities in Health, 1988).

Within Scotland, $73 \%$ of the geographical variation in CHD mortality could be explained by socio-environmental factors (Crombie et al. 1989), and much of the CHD mortality difference between Edinburgh and Glasgow may be explained by the different social-class structure of the two cities (Smith et al. 1990).

* Present address: Department of Applied Statistics, The University, Whiteknights, Reading RG6 IAN. 
As the result of men being considered the 'high-risk' group, frequently previous epidemiological studies of CHD risk factors, both in the UK (Marmot et al. 1978; Shaper et al. 1981; Caerphilly and Speedwell Collaborative Group, 1984), and internationally (Keys et al. 1967; Pooling Project Research Group, 1978), have not looked at women. Also, many have considered only the more traditional risk factors, with minimal dietary information. However, diet may be one of the fundamental components of 'life-style' which contribute to CHD risk (Marmot et al. 1975; Yano et al. 1978).

The data collected in the Scottish Heart Health Study (SHHS) (Smith et al. 1989; Tunstall-Pedoe et al. 1989) have allowed diet to be considered simultaneously with other risk factors for CHD, and for women as well as men to be examined in this respect. Preliminary findings have been reported (Bolton-Smith et al. $1990 a, b$ ) but this is the first full paper on the detailed nutritional findings from the SHHS, and it aims to describe the dietary characteristics of the different social-class groups. Subsequent papers will address the effect of age on nutrient intakes, consider nutrient sources and the relationships between other key risk factors and diet.

\section{METHODS}

The objectives and methods of the SHHS have been described previously (Smith et al. 1987, 1989). Briefly, a total of 10359 men and women aged 40-59 years from twenty-two districts in Scotland were recruited through 260 general practitioners. A questionnaire was completed at home, to give details on social factors, health, smoking, exercise and diet. This was checked for completeness by the study nurse when the subjects attended a clinic for the physical examination which included weight, height and blood pressure measurement and the taking of a non-fasted venous blood sample. Half the sampling was carried out during the summer months and half during the winter months between December 1984 and December 1986.

\section{Dietary evaluations}

Diet was assessed using a modified version of the food frequency questionnaire (FFQ) which was established by the Medical Research Council Cardiff Group (Yarnell et al. 1983). Groups of foods and portion sizes were largely unaltered, but alcohol intake was assessed by a $7 \mathrm{~d}$ structured recall question and standard drinks were adjusted to Scottish measures. Nutrient analysis was computerized and used the data from McCance and Widdowson's The Composition of Foods (Paul \& Southgate, 1978). Vitamin E and vitamin A were calculated as $\alpha$-tocopherol and retinol equivalents respectively (with $\beta$-carotene including other carotenoids). The analysis programme flagged questionnaires with nutrient values outwith set range limits (values available). Subjective assessments of validity were made based on examination of the questionnaires for obvious errors and inconsistencies and the estimation of maximum possible intakes if three full meals were consumed daily. Extreme low values of nutrients only occurred for women, when total energy intake was low. These questionnaires were universally excluded if below $2.5 \mathrm{MJ}$ or if the pattern of reported foods was considered extremely unlikely (by C. B.-S.). Total energy intakes which were otherwise low, but which resulted from apparently sound FFQ, were not excluded, for it was considered that this would unjustifiably bias the data.

Forty subjects also completed an identical FFQ 3-4 weeks after the initial one, as a measure of repeatability and within-subject variance. A supplementary questionnaire was completed by sixty-seven other subjects in order to monitor the importance of food items not specifically mentioned on the FFQ such as haggis, soup and fruit loaf. Further validation was supplied by comparison with weighed intake data (Bolton-Smith \& Milne, 1991) and by comparisons between dietary and serum levels of vitamins (Bolton-Smith 
et al. 1991). Mean nutrient intakes were rounded to three significant figures, except for vitamin $\mathrm{C}$ and vitamin $\mathrm{E}$, which were rounded to two significant figures.

\section{Classification by social class}

Classification by occupation was performed according to the coding index of the Office of Populations, Censuses and Surveys (OPCS), 1980 and by grouping into non-manual (N; , II, IIIN) and manual (M; IIIM, IV, V) occupations. Women were grouped according to their husband's occupation (see McDowall, 1983) and the currently unemployed by their last job. The effects of alternative classification according to housing tenure (owneroccupier (OO), local authority rented (LAR) and private rented) and by level of education (primary, secondary, professional and university) were also assessed.

\section{Statistical analyses and data presentation}

Statistical analyses included analysis of variance, paired $t$ testing, Pearson correlation and regression analysis performed with the Statistical Package for Social Sciences (SPSS ${ }^{\mathrm{x}}$, 1986). Two-tailed tests of significance were used throughout. Percentage contributions to total energy intake are expressed inclusive of alcohol, and nutrient densities are given as amounts per $4 \cdot 2 \mathrm{MJ}(1000 \mathrm{kcal})$. Before analysis, skewed distributions of nutrients were transformed appropriately to improve normality ( $\mathrm{g}$ alcohol, $\ln (\mathrm{g}$ alcohol +1$)$ transformed ; $\mu \mathrm{g}$ retinol and carotene $(\mu \mathrm{g}$ and $\mu \mathrm{g} / 4 \cdot 2 \mathrm{MJ}), \ln$ transformed, and all the percentage energy data, $\sqrt{ }$ arcsine transformed). The untransformed values are given in the tables and figures. Differences in nutrient intakes between the $\mathrm{N}$ and $\mathrm{M}$ groups were also tested for after adjustment for smoking habit (using the serum values for the stable metabolite of nicotine, cotinine).

In an attempt to avoid the discussion of spurious significant results at the $P<0.05$ level (which are bound to occur with such large numbers), the $P<0.01$ significance level is used for the analysis of nutrients by social class and sex.

\section{RESULTS}

\section{Compliance and exclusions}

The overall response rate in the SHHS was $74 \%$, and of these, $97.7 \%$ returned the FFQ in varying stages of completeness $(n$ 10121). The number of participants in the current analyses varies slightly depending on the method of grouping and the individual nutrient under consideration. This is due to the missing values which occur for all questions. Missing values for any nutrient did not exceed $2.5 \%$ except for saturated fat (SFA) and polyunsaturated fat (PUFA), $4.5 \%$. This was due to the brand of spreading fat or cooking oil not being specified.

Amongst those subjects excluded with incomplete FFQ or multiple nutrient outliers were five with energy intakes above $23 \mathrm{MJ}$ and obvious mis-interpretation of the questionnaire, and eleven with energy intakes below $2.5 \mathrm{MJ}$ (only one of these being on a slimming diet).

\section{Reproducibility and validity}

Results from the forty repeat questionnaires showed Pearson correlation coefficients for the individual nutrients ranging from $0 \cdot 70$ for fibre to 0.94 for sugar. The correlation coefficient for energy intake was 0.78 . Significant differences $(P<0.05)$ by paired $t$ test occurred only for fat (SFA and PUFA), sugar, alcohol, retinol and vitamin E. Analysis of the supplementary questionnaires revealed only two types of food which were consumed regularly and which were not present on the original FFQ. These were soups and sauces, 
Table 1. Distribution of the Scottish Heart Health Study population* between social-class groups

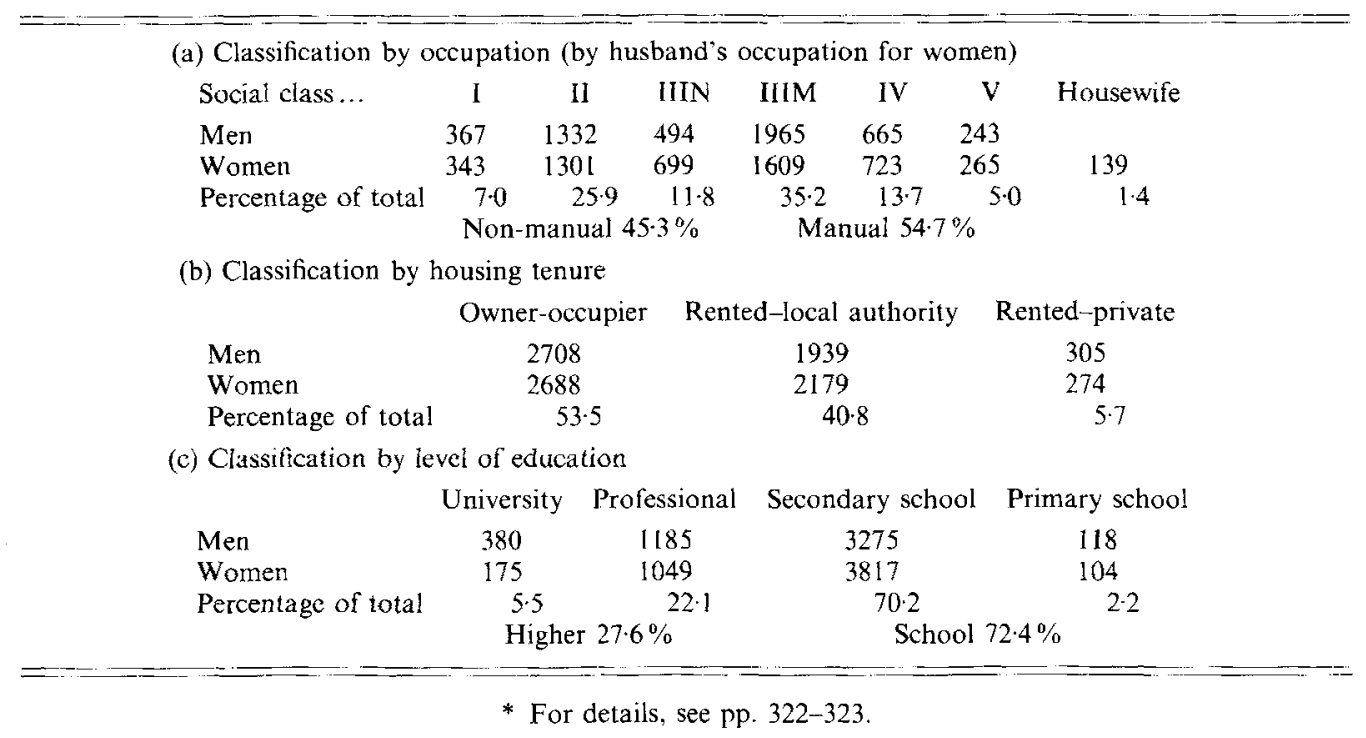

Table 2. Some further characteristics of the social-class groups of the Scottish Heart Health Study population*

\begin{tabular}{|c|c|c|c|c|c|c|c|}
\hline Social class $† \ldots . .$. & & I & II & IIIN & IIIM & IV & $\mathrm{V}$ \\
\hline Mean percentage unemployed & $\begin{array}{l}\text { Men } \\
\text { Women }\end{array}$ & $\begin{array}{l}2.5 \\
0.6\end{array}$ & $\begin{array}{l}3 \cdot 1 \\
1 \cdot 5\end{array}$ & $\begin{array}{l}6 \cdot 1 \\
4 \cdot 2\end{array}$ & $\begin{array}{r}12.2 \\
1.9\end{array}$ & $\begin{array}{r}15 \cdot 3 \\
4 \cdot 7\end{array}$ & $\begin{array}{r}21.8 \\
4.5\end{array}$ \\
\hline Mean percentage smokers & $\begin{array}{l}\text { Men } \\
\text { Women }\end{array}$ & $\begin{array}{l}21.5 \\
17.8\end{array}$ & $\begin{array}{l}26 \cdot 8 \\
27 \cdot 3\end{array}$ & $\begin{array}{l}32 \cdot 4 \\
34 \cdot 8\end{array}$ & $\begin{array}{l}46 \cdot 3 \\
45 \cdot 4\end{array}$ & $\begin{array}{l}47 \cdot 7 \\
46 \cdot 1\end{array}$ & $\begin{array}{l}58 \cdot 0 \\
48 \cdot 3\end{array}$ \\
\hline Mean height (m) & $\begin{array}{l}\text { Men } \\
\text { Women }\end{array}$ & $\begin{array}{l}1.81 \\
1.67\end{array}$ & $\begin{array}{l}1 \cdot 75 \\
1 \cdot 64\end{array}$ & $\begin{array}{l}1.76 \\
1.62\end{array}$ & $\begin{array}{l}1.75 \\
1.60\end{array}$ & $\begin{array}{l}1.74 \\
1.59\end{array}$ & $\begin{array}{l}1.70 \\
1.61\end{array}$ \\
\hline Mean BMI & $\begin{array}{l}\text { Men } \\
\text { Women }\end{array}$ & $\begin{array}{l}25 \cdot 3 \\
24 \cdot 2\end{array}$ & $\begin{array}{l}260 \\
24 \cdot 9\end{array}$ & $\begin{array}{l}26 \cdot 1 \\
25 \cdot 3\end{array}$ & $\begin{array}{l}26 \cdot 3 \\
26 \cdot 0\end{array}$ & $\begin{array}{l}26 \cdot 1 \\
26 \cdot 3\end{array}$ & $\begin{array}{l}260 \\
27 \cdot 0\end{array}$ \\
\hline
\end{tabular}

BMI, body mass index (weight $(\mathrm{kg}) /$ height $\left.(\mathrm{m})^{2}\right)$.

* For details, see pp. 322-323.

$\uparrow$ Social-class classification by occupation, according to the coding index of the Office of Populations, Censuses and Surveys (1980).

and jams and preserves $(30$ and $50 \%$ respectively consumed these more than three times a week).

\section{Classification by social class}

The distribution of the study population between the social-class groups is given in Table 1. Classification by occupation gave a wide variation in numbers between the groups, with $60.1 \%$ in the groups II and IIIM. However, combining the three $N(I, I I$ and IIIN) and the three $\mathrm{M}$ (IIIM, IV and $\mathrm{V}$ ) groups gave similar numbers in $\mathrm{N}$ and $\mathrm{M}$ groups for men and women. The $\mathrm{N}$ category accounts for $45.2 \%$ and the $\mathrm{M}$ category for $54.8 \%$ of the study population. The housewife group is small $(n 139)$ for this represents women who cannot be categorized by 'husband's occupation' and they are subsequently omitted from the dietary analysis. Alternative classification by housing tenure and level of education resulted in a 
Table 3. Distribution of people in the Scottish Heart Health Study population* on special diets by non-manual $(N)$ and manual $(M)$ occupational groups

\begin{tabular}{|c|c|c|c|c|c|c|c|}
\hline \multirow[b]{2}{*}{ Diet... } & & \multirow[b]{2}{*}{ Non-special } & \multicolumn{2}{|c|}{ Slimming } & \multirow[b]{2}{*}{ Diabetic } & \multirow{2}{*}{$\begin{array}{l}\text { Other } \\
\text { 'medical' }\end{array}$} & \multirow{2}{*}{$\begin{array}{c}\text { Vegetarian/ } \\
\text { vegan }\end{array}$} \\
\hline & & & Doctor & Self & & & \\
\hline \multirow[t]{2}{*}{ Men } & $\mathrm{N}$ & 2101 & 10 & 86 & 29 & 41 & 8 \\
\hline & $\mathbf{M}$ & 2665 & 27 & 83 & 33 & 40 & 3 \\
\hline \multirow[t]{2}{*}{ Women } & $N$ & 1933 & 25 & 265 & 18 & 58 & 19 \\
\hline & $\mathbf{M}$ & 2105 & 56 & 288 & 33 & 70 & 7 \\
\hline \multicolumn{8}{|c|}{ Percentage N } \\
\hline Men & & 43 & 27 & 51 & 47 & 51 & 73 \\
\hline Women & & 48 & 31 & 48 & 35 & 45 & 73 \\
\hline
\end{tabular}

* For details, see pp. 322-323.

more uneven distribution of the study population between sub-groups. Moreover, $77 \%$ of $\mathrm{N}$ and only $35 \%$ of $\mathrm{M}$ were in the $\mathrm{OO}$ group and $46 \%$ of $\mathrm{N}$ and only $10 \%$ of $\mathrm{M}$ occurred in the higher education group (university + professional), suggesting considerable overlap in these definitions. Classification by occupation (social class $\mathrm{I}-\mathrm{V}$, and $\mathrm{N}$ and $\mathrm{M}$ ) is adopted for the detailed dietary analyses, although some comparisons with education and housing tenure will be presented.

Table 2 gives some further characteristics of the social-class groups. More people are unemployed and smoke in the lower social classes, and heights are lower and BMI is higher, compared with the upper social classes. Table 3 gives the numerical breakdown of $\mathrm{N}$ and $M$ subjects by diet, with $12 \%$ reported to be on 'special diets'. The largest special group was the self-appointed slimmers (7.2\%), evenly divided between the $\mathrm{N}$ and $\mathrm{M}$ groups, but with the majority being women $(76.6 \%)$. Medically-prescribed slimming diets and diabetic diets each accounted for $1.2 \%$, while the 'Other' medical-diet group accounted for $2 \cdot 1 \%$. Vegetarians made up $0.4 \%$ of the study population and only one vegan was present.

\section{Nutrient intakes}

The mean values and standard deviations for total energy, and the quantities of nutrients consumed by men and women in the $\mathrm{N}$ and $\mathrm{M}$ occupational groups are presented in Table 4. For men, significant differences at the $P<0.01$ level or better, existed between the $\mathrm{N}$ and $M$ groups for all the nutrients, both with and without adjustment for serum cotinine levels (results not shown). For women however, non-significant differences $(P>0.01)$ occurred between the $\mathrm{N}$ and $\mathrm{M}$ groups for protein, PUFA and vitamin $\mathrm{A}$ levels both with and without adjustment for serum cotinine, and the $\mathrm{N}-\mathrm{M}$ difference in vitamin $\mathrm{E}$ intake became non-significant $(P=0.06)$ after adjustment was made for serum cotinine. Men in both the $\mathrm{N}$ and $\mathrm{M}$ groups had a higher mean energy intake than the respective categories for women. They also consumed significantly more of all the nutrients $(P<0.001)$ except vitamins $\mathrm{C}$ (ascorbic acid) and $\mathrm{A}$ (where no significant difference occurred) and $\beta$-carotene (where higher levels were consumed by women). Total energy intake was higher in the $\mathbf{M}$ group compared with the $\mathrm{N}$ group, by $13.2 \%$ for men and by $4.7 \%$ for women. For men, fat contributed $29 \%$ and carbohydrate $51 \%$ of the energy difference between the $\mathrm{N}$ and $\mathrm{M}$ groups, while for women, fat contributed $62 \%$ and carbohydrate $36 \%$ of this energy difference.

Fig. 1 presents the mean total energy intake and the percentage of energy $(\% \mathrm{En})$ from nutrients for the occupational groups I-V by sex. The mean values for the combined $\mathrm{N}$ and 
Table 4. Total energy, and nutrients consumed daily by people of the Scottish Heart Health Study population $\uparrow$ in non-manual and manual occupational groups

(Mean values and standard deviations, plus median values for highly-skewed distributions)

\begin{tabular}{|c|c|c|c|c|c|c|c|c|}
\hline \multirow{3}{*}{$n+\ldots$} & \multicolumn{4}{|c|}{ Men } & \multicolumn{4}{|c|}{ Women } \\
\hline & \multicolumn{2}{|c|}{$\begin{array}{l}\text { Non-manual } \\
2193\end{array}$} & \multicolumn{2}{|c|}{$\begin{array}{c}\text { Manual } \\
2873\end{array}$} & \multicolumn{2}{|c|}{$\begin{array}{l}\text { Non-manual } \\
2232\end{array}$} & \multicolumn{2}{|c|}{$\begin{array}{c}\text { Manual } \\
2597\end{array}$} \\
\hline & Mean & SD & Mean & SD & Mean & SD & Mean & SD \\
\hline Total energy $(\mathrm{kJ})$ & 9156 & $2292 * * *$ & 10363 & 2768 & 7169 & $1811^{* * *}$ & 7507 & 2145 \\
\hline Protein $(\mathrm{g})$ & $84 \cdot 3$ & $20^{* * *}$ & $90 \cdot 3$ & 23 & $74 \cdot 3$ & 17 & $74 \cdot 9$ & 21 \\
\hline Total fat $(\mathrm{g})$ & 85.6 & $26^{* * * *}$ & $95 \cdot 0$ & 29 & $74 \cdot 0$ & $23^{* * *}$ & $80 \cdot 5$ & 25 \\
\hline SFA (g) & $38 \cdot 1$ & $13^{* * * *}$ & $41 \cdot 7$ & 14 & $33 \cdot 6$ & $12^{* * *}$ & $36 \cdot 5$ & 13 \\
\hline PUFA (g) & $11 \cdot 3$ & $5 * * *$ & 11.9 & 5 & $9 \cdot 3$ & 5 & $9 \cdot 4$ & 5 \\
\hline Carbohydrate (g) & 255 & $78 * * *$ & 295 & 92 & 188 & $59 * *$ & 197 & 71 \\
\hline Sugar (g) & $95 \cdot 2$ & $42 * * *$ & $112 \cdot 5$ & 52 & $73 \cdot 0$ & $30^{* *}$ & $76 \cdot 9$ & 38 \\
\hline Starch $(g)$ & 160 & $54 * * *$ & 182 & 61 & 115 & $42^{* *}$ & 120 & 48 \\
\hline Alcohol (g) (median) & $\begin{array}{l}19 \cdot 1 \\
(12 \cdot 4)\end{array}$ & $21^{* * *}$ & $\begin{array}{c}23 \cdot 9 \\
(16 \cdot 2)\end{array}$ & 27 & $\begin{array}{c}6 \cdot 9 \\
(14 \cdot 1)\end{array}$ & $8 * * *$ & $\begin{array}{c}5 \cdot 4 \\
(2 \cdot 5)\end{array}$ & 8 \\
\hline Fibre $(\mathrm{g})$ & $22 \cdot 0$ & $8 * * *$ & $20 \cdot 7$ & 7 & $20 \cdot 5$ & $7^{* * *}$ & $18 \cdot 0$ & 7 \\
\hline Cholesterol (mg) & 369 & $146^{* * *}$ & 414 & 159 & 323 & $114^{* * *}$ & 345 & 127 \\
\hline Vitamin C (mg) & $56 \cdot 7$ & $22^{* * * *}$ & $50 \cdot 1$ & 21 & $56 \cdot 6$ & $24 * * *$ & $48 \cdot 1$ & 23 \\
\hline $\begin{array}{l}\text { Vilamin A ( } \mu \text { g) } \\
\text { (retinol equivalents) }\end{array}$ & 1244 & $1077^{* *}$ & 1312 & 1340 & 1264 & 1228 & 1282 & 931 \\
\hline Retinol $(\mu \mathrm{g})$ (median) & $\begin{array}{c}685 \\
(633)\end{array}$ & $373^{* * *}$ & $\begin{array}{c}791 \\
(691)\end{array}$ & 490 & $\begin{array}{c}670 \\
(620)\end{array}$ & $374 * * *$ & $\begin{array}{c}740 \\
(639)\end{array}$ & 480 \\
\hline$\beta$-Carotene $(\mu \mathrm{g})$ (median) & $\begin{array}{c}3344 \\
(3157)\end{array}$ & $2176^{* *}$ & $\begin{array}{c}3145 \\
(3078)\end{array}$ & 2165 & $\begin{array}{c}3556 \\
(3219)\end{array}$ & $2257^{* * *}$ & $\begin{array}{c}3267 \\
(3109)\end{array}$ & 22.89 \\
\hline $\begin{array}{l}\text { Vitamin E (mg) } \\
(\alpha \text {-tocopherol equivalents) }\end{array}$ & $7 \cdot 7$ & $5 \cdot 3 * * *$ & $7 \cdot 0$ & $4 \cdot 9$ & $6 \cdot 8$ & $5 \cdot 1^{* * *}$ & 6.1 & $4 \cdot 5$ \\
\hline
\end{tabular}

SFA, saturated fatty acids; PUFA, polyunsaturated fatty acids.

Mean values for the non-manual group were significantly different from those of the manual group by analysis of variance on the appropriately transformed data (see p. 323): ${ }^{* *} P<0 \cdot 01,{ }^{* * *} P<0.001$.

$\dagger$ For details, see pp. 322-323.

¥ Average number: small variations in $n$ occur between nutrients due to missing values.

Table 5. The percentage of the non-manual $(N)$ and manual $(M)$ occupational groups of the Scottish Heart Health Study population* who rarely or never $(R)$ and frequently $(F,>$ three times/week) eat fresh fruit and vegetables (veg)

\begin{tabular}{|c|c|c|c|c|c|c|c|}
\hline \multirow[b]{2}{*}{$n \ldots$} & & \multicolumn{3}{|r|}{ Men } & \multicolumn{3}{|r|}{ Women } \\
\hline & & $\begin{array}{c}N \\
2193\end{array}$ & $\begin{array}{c}\mathbf{M} \\
2873\end{array}$ & $\begin{array}{c}\text { Statistical significance } \\
\text { of difference }\left(\chi^{2}\right) \text { : } \\
p\end{array}$ & $\begin{array}{c}\mathrm{N} \\
2243\end{array}$ & $\begin{array}{c}M \\
2597\end{array}$ & $\begin{array}{c}\text { Statistical significance } \\
\text { of difference }\left(\chi^{2}\right) \text { : } \\
p\end{array}$ \\
\hline Fresh fruit & $\begin{array}{l}\mathrm{R} \\
\mathrm{F}\end{array}$ & $\begin{array}{l}15 \\
61\end{array}$ & $\begin{array}{l}24 \\
51\end{array}$ & $<0.001$ & $\begin{array}{r}7 \\
79\end{array}$ & $\begin{array}{l}21 \\
61\end{array}$ & $<0.001$ \\
\hline Green veg & $\begin{array}{l}\mathrm{R} \\
\mathrm{F}\end{array}$ & $\begin{array}{r}8 \\
54\end{array}$ & $\begin{array}{l}15 \\
40\end{array}$ & $<0.001$ & $\begin{array}{r}5 \\
64\end{array}$ & $\begin{array}{r}8 \\
50\end{array}$ & $<0.001$ \\
\hline Root veg & $\begin{array}{l}\mathrm{R} \\
\mathrm{F}\end{array}$ & $\begin{array}{l}12 \\
46\end{array}$ & $\begin{array}{l}14 \\
48\end{array}$ & 0.013 & $\begin{array}{l}10 \\
50\end{array}$ & $\begin{array}{l}11 \\
48\end{array}$ & NS \\
\hline
\end{tabular}

NS, not significant.

* For details, see pp. 322-323. 


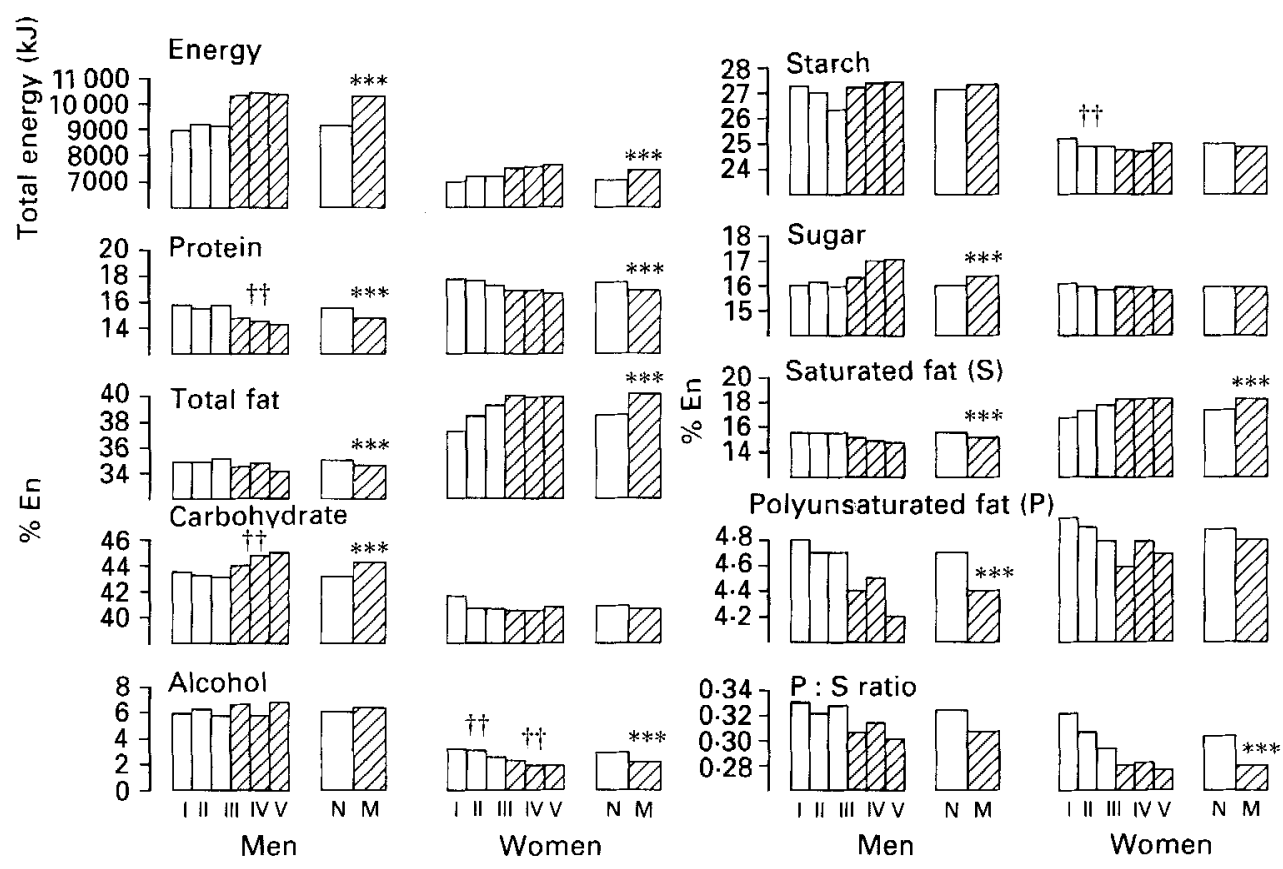

Fig. 1. Total energy intake (inclusive of alcohol) and percentage contribution from nutrients to total energy in the Scottish Heart Health Study population (for details, see pp. 322-323) by sex and social-class group. Social-class classification I-V according to occupation (Office of Populations, Censuses and Surveys, 1980). Values are means for an average of 2268 non-manual $(N ; \square)$ and 2735 manual $(M ; \square)$ subjects. Mean values were significantly different by analysis of variance on the appropriately transformed data (see p. 323); between $N$ and $M$ groups $\left({ }^{* * *} P<0.001\right)$ and within $\mathrm{N}$ or $\mathrm{M}$ groups $(\dagger+P<0.01)$.

$\mathrm{M}$ groups are also given. In most cases, clear nutritional distinctions exist between the $\mathrm{N}$ groups (I, II and IIIN) and the $\mathrm{M}$ groups (IIIM, IV and V). The decline in the P:S ratio from social class $\mathrm{I}-\mathrm{V}$ for men $(\mathrm{N} 0.32, \mathrm{M} 0.31 ; P=0.025)$ was largely due to a relatively lower PUFA intake, while the decline for women (N 0.31, M $0.28 ; P<0.001)$ was due to a relative increase in SFA intake.

Nutrient densities (amounts/4.2 MJ (1000 kcal)) are presented, in a similar format to the $\%$ En values, in Fig. 2 . The lower intakes of vitamins $\mathrm{C}$ and $\mathrm{E}$ and $\beta$-carotene in the $\mathrm{M}$ than the $\mathrm{N}$ groups coincide with less-frequent consumption of fresh fruit and green vegetables in the $\mathrm{M}$ groups, but less well with the frequency of root-vegetable consumption (Table 5).

The cholesterol nutrient density values did not differ significantly between the individual social-class groups or between the $\mathrm{N}$ and $\mathrm{M}$ groups for men (mean for both groups 196 (SD 100) $\mathrm{mg} / 4 \cdot 2 \mathrm{MJ}$ ). For women, the values for the $\mathrm{N}$ (mean 190 (SD 71) $\mathrm{mg} / 4 \cdot 2 \mathrm{MJ}$ ) and $\mathrm{M}$ (mean 196 (SD 51) $\mathrm{mg} / 4 \cdot 2 \mathrm{MJ}$ ) groups differed significantly $(P<0.01)$, but only by $5 \mathrm{mg} / 4 \cdot 2 \mathrm{MJ}$. The maximum difference between social-class groups $\mathrm{I}$ and $\mathrm{V}$ was $15 \mathrm{mg} / 4 \cdot 2 \mathrm{MJ}$ for women.

Table 6 compares the energy distribution between the nutrients when classification was by occupation (N-M), housing tenure (OO-LAR) and level of education (higher-school). Similar results were seen for each method of grouping, especially for women. When further sub-division of the $\mathrm{N}$ and $\mathrm{M}$ categories, by either housing tenure or education group, was performed (values available) the same $\mathrm{N}-\mathrm{M}$ trends in nutrient intakes occurred for each housing or education category. By multiple-regression analysis, social-class differences in nutrient intakes were not confounded by either education level or housing tenure, with the 

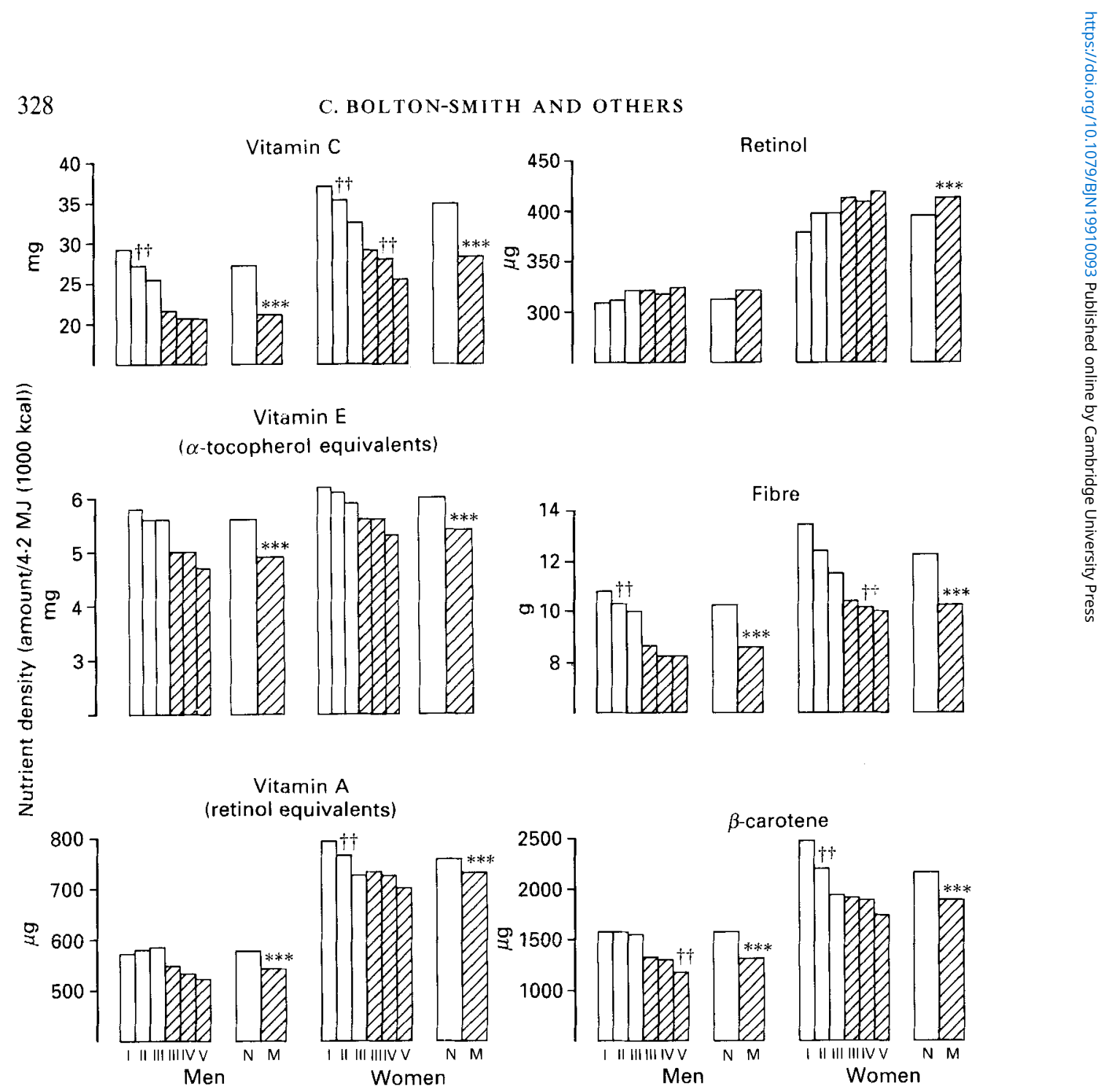

Fig. 2. Nutrient densities for social-class groups in the Scottish Heart Health Study population (for details, see pp. 322-323). Social-class classification I-V according to occupation (Office of Populations, Censuses and Surveys, 1980). Values are means (per $4.2 \mathrm{MJ}(1000 \mathrm{kcal})$ ) for an average of 2268 non-manual $(\mathrm{N} ; \square)$ and $2735 \mathrm{manual}$ $(\mathrm{M} ; \nabla)$ subjects. Mean values were significantly different by analysis of variance on the appropriately transformed data (see p. 323); between $\mathrm{N}$ and $\mathrm{M}$ groups $\left({ }^{* * *} P<0.001\right)$ and within $\mathrm{N}$ or $\mathrm{M}$ groups $(\dagger \dagger P<0.005)$.

exception of sugar intake (housing and education) and carbohydrate intake (education level only) for men.

\section{DISCUSSION}

The study population may be considered a good representation of the Scottish population for the distribution between the social-class groups is comparable with the 1981 census data (Registrar General Scotland, 1984). The higher stature of those in the higher social-class groups, and the higher BMI of those in the lower social-class groups, have been reported previously (Fehily et al. 1984; Knight, 1984) and may be indicative of poor diet, as well as other factors of social disadvantage. The characteristic tendency for a higher proportion of those in $\mathbf{M}$ occupations to smoke and to be unemployed, is also shown in the SHHS findings.

The percentage of people reporting to be on a special diet (men $7.0 \%$, women $17.2 \%$ ) are 


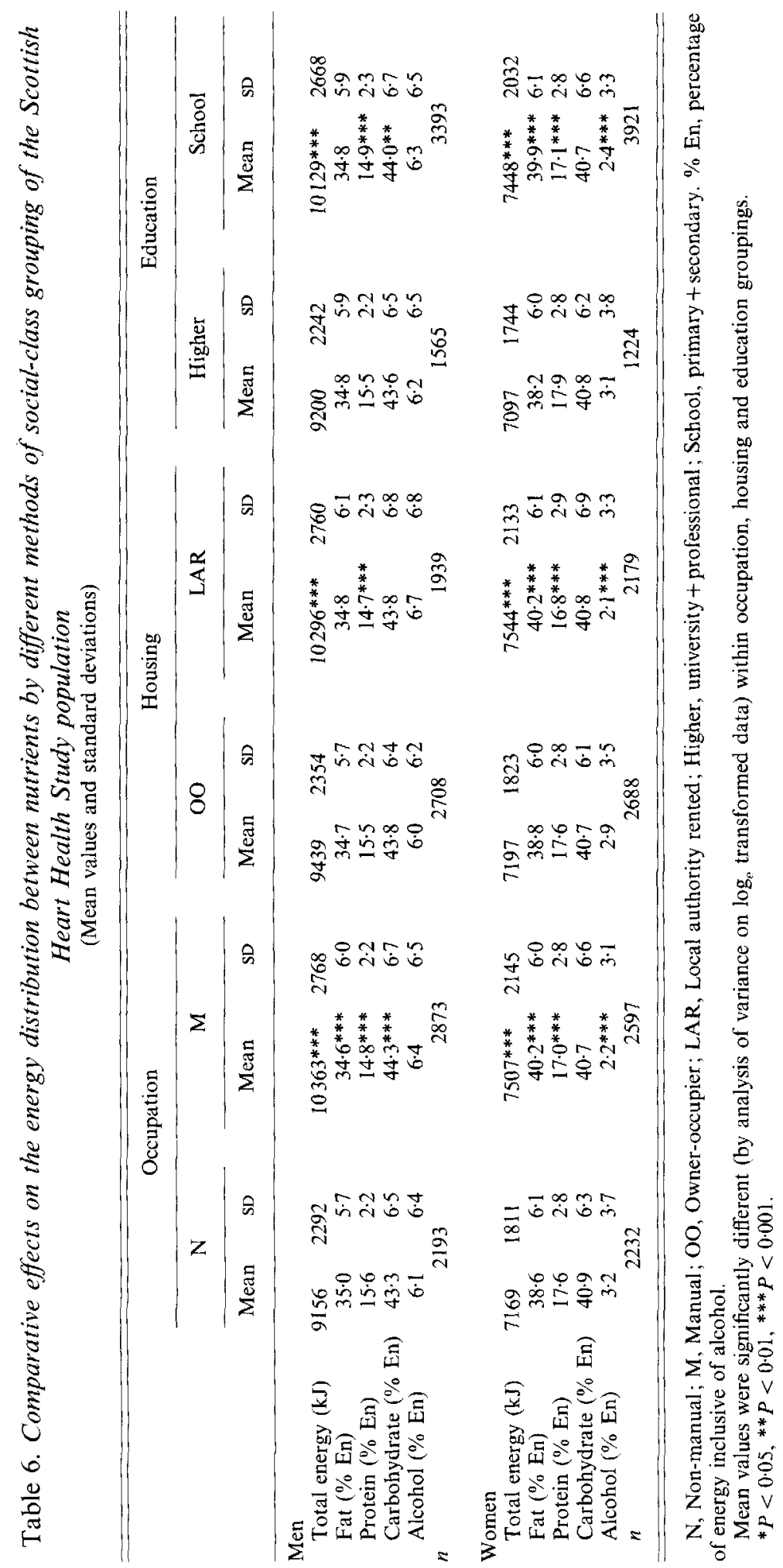


comparable with the values from the Northern Ireland study (Barker et al. 1989) of 8.2\% for men and $19.5 \%$ for women, but the percentage on medically-prescribed diets is somewhat lower than those reported in other studies (Thomson et al. 1985; Cox et al. 1987), as is the percentage of slimmers compared with the OPCS report (Knight, 1984).

While it is clear that energy intakes slightly above the lower cut-off of $2.5 \mathrm{MJ}$ are well below basal metabolic rate, their removal would bias the data towards the higher intakes, where we have no objective view of validity. Until a standardized procedure for accepting and rejecting dietary data at both extremes of intake is available and validated, selective removal of low intake data, when it is not based on obvious inaccuracy or misunderstanding, will not help in the determination of accurate means for population groups. The limitations of the food-frequency technique, and all other methods of dietary assessment, have been extensively reviewed (Cameron \& Van Staveren, 1988), and while it is recognized that no one method of dietary assessment is perfect, the FFQ is considered to give a reliable indication of dietary intakes for groups, but not individuals. Both the reproducibility, and the indicators of validity, for the FFQ in the Scottish population suggested that the method of dietary recording was satisfactory for the aim of the study, namely, the assessment of the average diet of the Scottish population and sub-sets thereof. Specifically, reproducibility was good, with Pearson correlation coefficients between 0.7 and 0.94 , and remarkably few significant differences between the mean nutrient values by paired $t$ test analysis. Correlation coefficients were higher than those of $0.52-0.71$ found by Willett et al. (1985), but the repeat questionnaires were filled in with only a 1 -month interval compared with 12 months in the study quoted, which may, therefore, also reflect a change in diet over the year. Comparison between nutrient intakes obtained from the questionnaire and from weighed intake data (Bolton-Smith \& Milne, 1991) found a similar range of significant Pearson correlation coefficients $(0 \cdot 28-0.64)$ to that reported in the original assessment of the questionnaire in the Welsh population $(0 \cdot 30-0 \cdot 70$; Yarnell et al. 1983).

According to the supplementary questionnaires, jams and preserves, and soups and sauces were the only two types of food which were regularly consumed and not included in the standard FFQ. This may account for the lower total energy values compared with weighed intake data from Edinburgh men (Thomson et al. 1985), for soups, sauces and miscellaneous foods contributed a mean of $2.4 \%$ of total energy in their study. However, more recent studies using the weighed-intake technique have indicated similar energy intakes to those found here (Braddon et al. 1988; Barker et al. 1989; Gregory et al. 1990), and there is a trend for energy intakes to be declining (Ministry of Agriculture, Fisheries and Food (MAFF), 1987).

The National Food Survey (NFS) data for the years covering the present study (MAFF, 1986 and 1987) reported comparable differences in energy intakes between income groups, to those found here for social-class groups. Similar significant differences between $\mathrm{N}$ and $\mathrm{M}$ groups have been reported for men by some workers (Fehily et al. 1984; Braddon et al. 1988), but not by the recent survey of British adults (Gregory et al. 1990). The differences in diet which they report to occur between regions and age-groups may well have confounded the social-class effect in this national survey of 16 to 64-year-olds. Studies of smaller numbers (Bingham et al. 1981; Fulton et al. 1988; Barker et al. 1989) have been unable to detect significant differences, presumably because of the large intra- and interindividual variance which occurs in dietary intake and its measurement (Cameron \& Van Staveren, 1988; Nelson et al. 1989).

Braddon et al. (1988) found no significant differences in energy intake by social class for women, and Gregory et al. (1990) reported lower energy intakes in $\mathrm{M}$ women compared with $\mathrm{N}$ women. These latter energy values are low, however, and may possibly reflect problems of the $\mathrm{M}$ women in completing the relatively arduous $7 \mathrm{~d}$ weighed record of food intake. 
Other studies which have looked specifically at women have tended to concentrate on the pregnant or lactating states (for example, Black et al. 1986; Schofield et al. 1987), and as such, the higher energy intakes found in $\mathrm{N}$ compared with $\mathrm{M}$ women are not directly comparable with the present results. However, it is interesting to note, that even in these women, intakes of vitamins $\mathrm{C}$ and $\mathrm{E}$ and $\beta$-carotene are lower in the $\mathrm{M}$ groups, while retinol levels are not significantly different. Retinol often appears to be atypical, for intake in the SHHS is higher in the lower social-class groups, even after adjustment for energy intake, and this trend is also seen in the NFS data (MAFF, 1986, 1987) and for men in the survey of British adults (Gregory et al. 1990).

The lower intake of antioxidant vitamins in the $\mathrm{M}$ groups than the $\mathrm{N}$ groups seems to reflect the less frequent consumption of fresh fruit and vegetables, but more detailed analysis is necessary for the $\beta$-carotene intakes do not accord with the reported frequencies of total root vegetable consumption or with those of carrots alone (results not shown; full nutrient source data will be published separately). Other studies which have looked at nutrient intake by social class have found significantly lower vitamin $C$ levels in $M$ than $N$ groups (Fehily et al. 1984; Braddon et al. 1988). The results in the former study were also standardized for smoking, but revealed additional significant differences, between socialclass groups, only for total energy and carbohydrate (g), although a non-significant difference of $17 \%$ in $\beta$-carotene was shown between the $\mathrm{N}$ and $\mathrm{M}$ groups. Lower intakes of all the antioxidant vitamins (expressed per 4.2 MJ $(1000 \mathrm{kcal})$ ), with the exception of retinol for men, are reported for the lower social-class groups by Gregory et al. (1990). Their reported mean values tend to be higher than those in the SHHS, for all but $\beta$ carotene, but the median values are similar or lower, reflecting the highly-skewed nature of the data. The higher $\beta$-carotene values in the SHHS reflect the older age-group and the higher percentage of people consuming carrots $(90 \mathrm{v} .60 \%)$.

Fulton et al. (1988) did not analyse antioxidant vitamin intakes, and reported significant differences between social classes for only fibre and several specific fatty acids but not the $P: S$ ratio. Calculations of $P: S$ ratios from FFQ data are bound to be imprecise, but the large numbers in the study, and the FFQ validity for group estimations of nutrients, make the calculation tenable. Moreover, the P:S ratios, as calculated from the 1985 and 1986 NFS data for Scotland (MAFF, 1986, 1987), are very similar to those reported here, but both sets are lower than the value of 0.37 reported by Gregory et al. (1990). However, they do all confirm that the Scottish values are low compared with the rest of the UK.

The only other reported estimations of dietary vitamin $\mathrm{E}$ intake in UK populations come from the NFS data (Bull \& Buss, 1982; Lewis \& Buss, 1988). The mean intake of $7.8 \mathrm{mg} / \mathrm{d}$ for Scotland which was reported by Lewis \& Buss (1988) is very similar to the value reported here for $\mathrm{N}$ men $(7.7 \mathrm{mg} / \mathrm{d})$, but higher than those reported here for $\mathrm{M}$ men $(7.0 \mathrm{mg} / \mathrm{d})$ and for women $(\mathrm{N} 6.8 \mathrm{mg} / \mathrm{d}, \mathrm{M} 6.1 \mathrm{mg} / \mathrm{d})$. The difference in vitamin $\mathrm{E}$ intake between the lowest and the highest income groups of $0.9 \mathrm{mg} / \mathrm{d}$ was lower than that of $1.4 \mathrm{mg} / \mathrm{d}$ found here between the social-class groups I and $\mathrm{V}$ for both men and women. The differences probably reflect the different methods of classification and the relative inaccuracy of the household data, with no sex differentiation, compared with the FFQ data. The differences in the nutrient-density values between the upper- and lower-social-class groups were similar to those of $0.8-0.9 \mathrm{mg} / 4.2 \mathrm{MJ}(1000 \mathrm{kcal})$ which were reported from the weighed-intake data by Gregory et al. (1990).

In an analysis of the interactions (with respect to diet) between origin, education and social class in a Jerusalem population sample (Kaufmann et al. 1982), differences between social class, education and sex were found, and the literature extensively reviewed. Detailed comparisons are not made here between the Israeli, United States and Scottish data sets, for it is apparent that cultural differences between countries may be greater than the social class and educational differences within a country. However, lower intake of vitamins in the 
lower social-class groups does appear to be an international occurrence (Kaufmann et al. 1982).

In this Scottish population, trends in nutrient intakes between education level and housing tenure group were separate and additional to those between the $\mathrm{N}$ and $\mathrm{M}$ occupational groups. Braddon et al. (1988) reported a similar effect for education and social class. Standardized mortality rates have been shown to increase from OO to rented categories within any occupational group. However, despite this, classification by occupation still incorporates more aspects of social class than any other single method, as is discussed in the Black Report (see Inequalities in Health, 1988).

A possible caveat to the analysis of dietary intake by sub-groups is the extent to which results may be biased by differential reporting between them. Although the accuracy of reporting may vary for different nutrients, when considering group comparisons within a single data set, these effects will be consistent and so relatively unimportant, so long as any bias is indeed uniform between the groups. While it is difficult to judge to what extent accuracy of reporting varies between the sexes, and the social-class groups, several factors suggest that the bias may be reasonably consistent in the present study. First, a higher energy intake in the male $\mathrm{M}$ compared with the $\mathrm{N}$ groups would be expected, given that a greater energy output is (by definition) necessary during the daily occupation of manual workers. Furthermore, this trend has been previously reported in studies using different methods of dietary assessment (Fehily et al. 1984; Braddon et al. 1988). Second, similar trends in nutrient intakes occur for all three measures of socio-economic group (occupation, education and housing). Third, the energy intake: basal metabolic rate ratio (EN:BMR; estimated from body-weight according to Schofield, 1985) increased in the M compared with the $\mathrm{N}$ group for men (independent of $\mathrm{BMI}$ ), while for women the EN:BMR did not change significantly with social-class group although BMI increased from $24 \cdot 2$ in socialclass group I to 27.0 in group V (C. Bolton-Smith, unpublished results). This would suggest that either $\mathrm{N}$ men under-report their food consumption to a greater extent than $\mathrm{M}$ men, or that $\mathrm{M}$ men eat more due to their higher energy output (as is suggested by considering their energy intake data alone). As women are classified by their husbands' occupation, a higher energy output in the $M$ group is not inevitable, and the unchanged EN:BMR between the $\mathrm{N}$ and $\mathrm{M}$ groups might be expected. Thus, whilst differential reporting of food intake by sex and social class cannot be completely ruled out, there does not appear to be any clear information which suggests that it has strongly influenced the present results. (Further analysis is proceeding.)

In the UK, the different risk of CHD according to social-class group has been suggested to be largely due to altered haemostatic factors resulting from smoking (Baker et al. 1988). While smoking is undoubtedly a major risk factor, the present differences in nutrient intake between the $\mathrm{N}$ and $\mathrm{M}$ groups were independent of serum cotinine values, and Duijkers et al. (1989) also reported that social class was a risk factor for CHD in 40-49-year-old Dutch men, independent of blood pressure and cigarette smoking.

A study of trends in fat consumption, based on the NFS data for 1974 and 1981, concluded that 'recent social class trends in dietary fat intake are unlikely to account for the differential in CHD mortality' (Morgan et al. 1989). From the current analysis, it is likely that trends in fat intake between social-class groups are opposite for men and women and, thus, the NFS data, which do not distinguish between the sexes, may be misleading in this respect. Furthermore, no single factor, dietary or otherwise, is likely to explain fully the differentials in CHD mortality rates.

Low total energy and fibre intakes, and a low dietary $\mathrm{P}: \mathrm{S}$ ratio have been associated with increased incidence of CHD in prospective studies of men (Morris et al. 1977; Gordon et al. 1981; Kromhout \& Coulander, 1984; Kushi et al. 1985) and low energy intake with 
increased CHD incidence in women in Gothenburg (Lapidus et al. 1986). Recently, serum levels of antioxidant vitamins (which reflect dietary intake to varying degrees for different vitamins (Bolton-Smith et al. 1991)) have been strongly associated with CHD mortality in an ecological study (Gey et al. 1991). The trend for lower antioxidant vitamin and fibre intakes, and a lower $\mathrm{P}: \mathrm{S}$ ratio in the $\mathrm{M}$ occupational groups does also follow the national trend in standard mortality rates (SMR) for CHD by social class, both for men (Pocock et al. 1987) and for women (Heller et al. 1984). Furthermore, the regional Scottish SMR for CHD do also correlate well with social class and other socio-economic indicators (Crombie et al. 1989).

Total energy intake on the other hand is higher in the $M$ social classes, but this may not necessarily contradict the trends in CHD incidence and mortality, for aerobic exercise may be the cardio-protective form of physical activity, and this is more strongly associated with strenuous physical activity at leisure (and, thus, higher energy intake) rather than with physical activity at work (Holme et al. 1981; Paffenbarger et al. 1984).

While significant differences in nutrient intakes between social-class groups (at $P<0.01$ or better) have been shown in this Scottish population, the percentage energy differences are still small (1-3\%). However, the nutrient density values for fibre, vitamins $\mathrm{C}$ and $\mathrm{E}$ and $\beta$-carotene are $20-25 \%$ lower in social-class group V compared with group $\mathrm{I}$, and the $\mathrm{P}: \mathrm{S}$ ratio is lower by $10-15 \%$. It is possible that the combined effects of the differences in nutrient intakes may have an appreciable influence on CHD risk. Differences in nutrient intakes and energy distribution between nutrients probably reflect differences in eating habits and predominant food types between social-class groups, as has been suggested by some studies (Cox et al. 1987; Barker et al. 1989; Whichelow, 1989). The differences in nutrient sources between the social-class groups is currently being analysed, and may shed more light on why nutrient intakes differ between social-class groups.

Understanding why a poorer-quality diet is consumed by those in $M$ occupations may facilitate the formulation of strategies to improve it, and may thereby also contribute to a reduction in $\mathrm{CHD}$ risk in these highly susceptible groups.

The Scottish Home and Health Department provided funding for the SHHS, and C. B.-S. is funded by the British Heart Foundation.

Sincere thanks go to the Medical Research Council, Cardiff Group for their provision of, and assistance with the setting-up of the food-frequency questionnaire and analysis programme, and to $\mathrm{Mr}$ Colin Brown for computing and data management.

The opinions expressed in this paper are those of the authors alone.

\section{REFERENCES}

Baker, I. A., Sweetnam, P. M., Yarnell, J. W. G., Bainton, D. \& Elwood, P. C. (1988). Haemostatic and other risk factors for ischaemic heart disease and social class: evidence from the Caerphilly and Speedwell Studies. International Journal of Epidemiology 17, 759.765.

Barker, M. E., McClean, S. I., McKenna, P. G., Reid, N. G., Strain, J. J., Thompson, K. A., Williamson, A. P. \& Wright, M. E. (1989). Diet, Lifestyle and Health in Northern Ireland. Coleraine: University of Ulster, Northern Ireland.

Bingham, S., McNeil, N. I. \& Cummings, J. H. (1981). The diet of individuals: a study of a randomly-chosen cross section of British adults in a Cambridgeshire village. British Journal of Nutrition 45, 23-35.

Black, A. E., Wiles, S. J. \& Paul, A. A. (1986). The nutrient intakes of pregnant and lactating mothers of good socio-economic status in Cambridge, U.K: some implications for recommended daily allowances of minor nutricnts. British Journal of Nutrition 56, 59-72.

Bolton-Smith, C., Casey, C. E., Gey, K. F., Smith, W. C. S. \& Tunstall-Pedoe, H. (1991). Antioxidant vitamin intakes assessed using a food-frequency questionnaire : correlation with biochemical status in smokers and nonsmokers. British Journal of Nutrition 65, 337-346.

Bolton-Smith, C. \& Milne, A. C. (1991). Food frequency v. weighed intake data in Scottish men. Proceedings of the Nutrition Society (In the Press.) 
Bolton-Smith, C., Smith, W. C. S., Woodward, M., Brown, C. A. \& Tunstall-Pedoe, H. (1990a). Dietary differences between social-class groups in the Scottish Heart Health Study. Proceedings of the Nutrition Society 49, 62A.

Bolton-Smith, C., Smith, W. C. S., Woodward, M. \& Tunstall-Pedoe, H. (1990 b). Age trends in nutrient intakes for non-manual and manual occupational groups : the Scottish Heart Health Study. Proceedings of the Nutrition Society 49, 63A.

Braddon, F. E. M., Wadsworth, M. E. J., Davies, J. M. C. \& Cripps, H. A. (1988). Social and regional differences in food and alcohol consumption and their measurement in a national birth cohort. Journal of Epidemiology and Community Health 42, 341-349.

Bull, N. L. \& Buss, D. H. (1982). Biotin, pantothenic acid and vitamin E in the British household food supply. Human Nutrition: Applied Nutrition 36A, 190-196.

Caerphilly and Speedwell Collaborative Group (1984). The Caerphilly and Speedwell Collaborative Study. Journal of Epidemiology and Community Health 38, 259-262.

Cameron, M. E. \& Van Staveren, W. A. (1988). Manual on Methodology for Food Consumption Studies. New York: Oxford University Press.

Cox, B., Blaxter, M., Buckle, A. L. J., Fenner, N. P., Golding, J. F., Gore, M., Huppert, F. A., Nickson, J., Roth, M., Stark, J., Wadsworth, M. E. J. \& Whichelow, M. (1987). The Health and Lifestyle Survey. London: Health Promotion Research Trust.

Crombie, I. K., Kenicer, M. B., Smith, W. C. S. \& Tunstall-Pedoe, H. D. (1989). Unemployment, socioenvironmental factors and coronary heart disease in Scotland. British Heart Journal 61, 172-177.

Duijkers, T. J., Kromhout, D., Spruit, I. P. \& Doornbos, G. (1989). Inter-mediating risk factors in the relation between socioeconomic status and 25-year mortality (the Zutphen Study). International Journal of Epidemiology 18, 658-662.

Fehily, A. M., Phillips, K. M. \& Yarnell, J. W. G. (1984). Diet, smoking, social class and body mass index in the Caerphilly Heart Disease Study. American Journal of Clinical Nutrition 40, 827-833.

Fulton, M., Thomson, M., Elton, R. A., Brown, S., Wood, D. A. \& Oliver, M. F. (1988). Cigarette smoking, social class and nutrient intake : relevance to coronary heart disease. European Journal of Clinical Nutrition $\mathbf{4 2}$, 797-803.

Gey, K. F., Puska, P., Jordan, P. \& Moser, U. K. (1991). Inverse correlation between plasma vitamin E and mortality from ischaemic heart disease in cross-cultural epidemiology. American Journal of Clinical Nutrition 53, 5265-5345.

Gordon, T., Kagan, A., Garcia-Palmieri, M., Kannel, W. B., Zukel, W. J., Tillotson, J., Sorlie, P. \& Hjortland, M. (1981). Diet and its relation to coronary heart disease and death in three populations. Circulation 63, 500-515.

Gregory, J., Foster, K., Tyler, H. \& Wiseman, M. (1990). The Dietary and Nutritional Survey of British Adults. London: H.M. Stationery Office.

Heller, R. F., Williams, H. \& Sittampalam, Y. (1984). Social class and ischaemic heart disease: use of the male:female ratio to identify possible occupational hazards. Journal of Epidemiology and Community Health $\mathbf{3 8}$, $198-202$

Holme, I., Helgeland, A., Hjermann, I., Leren, P. \& Lund-Larsen, P. G. (1981). Physical activity at work and leisure in relation to coronary risk factors and social class. Acta Medica Scandinavica 209, 277-283.

Inequalities in Health (1988). The Black Report and the Health Divide. London: Penguin Books.

Kaufmann, N. A., Kark, J. D., Friedlander, Y., Dennis, B. H., McClish, D. \& Stein, Y. (1982). Nutrient intake in Jerusalem - effects of origin, social class and education. Israel Journal of Medical Sciences 18, 1198-1209.

Keys, A., Aravanis, C., Blackburn, H. W., van Buchem, F. S. P., Buzina, R., Djordjevic, B. S., Dontas, A. S., Fidanza, F., Karvonen, M. J., Kimura, N., Lekos, D., Monti, M., Puddu, V. \& Taylor, H. L. (1967). Epidemiological studies related to coronary heart disease: characteristics of men aged 40-59 in seven countries. Acta Medica Scandinavica 460, Suppl.

Knight, I. (1984). The Heights and Weights of Adults in Great Britain. London: H.M. Stationery Office.

Kromhout, D. \& Coulander, C. de L. (1984). Diet, prevalence and 10-year mortality from coronary heart disease in 871 middle-aged men. American Journal of Epidemiology 119, 733-741.

Kushi, L. H., Lew, R. A., Stare, F. J., Ellison, C. R., Lozy, M., Bourke, G., Daly, L., Graham, I., Hickey, N., Mulcahy, R. \& Kevaney, J. (1985). Diet and 20-year mortality from coronary heart disease. New England Journal of Medicine 312, 811-818.

Lapidus, L., Andersson, H., Bengtsson, C. \& Bosaeus, I. (1986). Dietary habits in relation to incidence of cardiovascular disease and death in women: a 12-year follow-up of participants in the population study of women in Gothenburg, Sweden. American Journal of Clinical Nutrition 44, 444-448.

Lewis, J. \& Buss, D. H. (1988). Trace nutrients: minerals and vitamins in the British household food supply. British Journal of Nutrition 60, 413-424.

McDowall, M. E. (1983). Measuring women's occupational mortality. Population Trends 34, 25.

Marmot, M. G. \& McDowall, M. E. (1986). Mortality decline and widening social inequalities. Lancet ii, $274-276$.

Marmot, M. G., Rose, G., Shipley, M.\& Hamilton, P. J. S. (1978). Employment grade and coronary heart disease in British civil servants. Journal of Epidemiology and Community Health 32, 244-249.

Marmot, M. G., Syme, S. L., Kagan, A., Kato, H., Cohen, J. B. \& Belsky, J. (1975). Epidemiological studies of 
coronary heart disease and stroke in Japanese men living in Japan, Hawaii and California : prevalence of coronary and hypertensive heart disease and associated risk factors. American Journal of Epidemiology 120 , $514-525$

Ministry of Agriculture, Fisheries and Food (1986). Household Food Consumption and Expenditure: 1985. London: H.M. Stationery Office.

Ministry of Agriculture, Fisheries and Food (1987). Household Food Consumption and Expenditure: 1986 London: H.M. Stationery Office.

Morgan, M., Heller, R. F. \& Swerdlaw, A. (1989). Changes in diet and coronary heart disease mortality among social classes in Great Britain. Journal of Epidemiology and Community Health 43, 162-167.

Morris, J. N., Marr, J. W. \& Clayton, D. G. (1977). Diet and heart disease: a postscript. British Medical Journal ii, $1307-1314$.

Nelson, M., Black, A. E., Morris, J. A. \& Cole, T. J. (1989). Between- and within-subject variation in nutrient intake from infancy to old age: estimating the number of days required to rank dietary intakes with desired precision. American Journal of Clinical Nutrition 50, 155-167.

Office of Populations, Censuses and Surveys (1980). Classification of Occupation. London: H.M. Stationery Office.

Paffenbarger, R. S., Hyde, R. T., Wing, A. L. \& Steinmetz, C. H. (1984). A natural history of athleticism and cardiovascular health. Joumal of the American Medical Association 252, 491-495.

Paul, A. A. \& Southgate, D. A. T. (1978). Mc Cance and Widdowson's Composition of Foods, 4th ed. London: H.M. Stationery Office.

Pocock, S. J., Shaper, A. G., Cook, D. G., Phillips, A. N. \& Walker, M. (1987). Social class differences in ischaemic heart disease in British men. Lancet ii, 197-201.

Pooling Project Research Group (1978). Relationship of blood pressure, serum cholesterol, smoking habit, relative weight and ECG abnormalities to incidence of major coronary events: final report of the Pooling Project. Journal of Chronic Disease 31, 201-306.

Registrar General Scotland (1984). Economic Activity (10\% Sample) Census 1981, Scotland. Edinburgh: H.M. Stationery Office.

Schofield, C., Wheeler, E. \& Stewart, J. (1987). The diets of pregnant and post-pregnant women in different socialclass groups in London and Edinburgh: energy, protein, fat and fibre. British Journal of Nutrition 58, 369-381.

Schofield, W. N. (1985). Predicting basal metabolic rate, new standards and review of previous work. Human Nutrition: Clinical Nutrition 39C, Suppl. 1, 5-4I.

Shaper, A. G., Pocock, S. J., Walker, M., Cohen, N. M., Wale, C. J. \& Thomson, A. G. (1981). British Regional Heart Study: Cardiovascular risk factors in middle-aged men in 24 towns. British Medical Journal 283, $179-186$.

Smith, W. C. S., Crombie, I. K., Irving, J. M., Kenicer, M. B. \& Tunstall-Pedoe, H. D. (1987). The Scottish Heart Health Study: objectives and development of methods. Health Bulletin 45, 211-217.

Smith, W. C. S., Shewry, M. C., Tunstall-Pedoe, H., Crombie, I. K. \& Tavendale, R. (1990). Cardiovascular disease in Edinburgh and North Glasgow - a tale of two cities. Journal of Clinical Epidemiology 43, 637-643.

Smith, W. C. S., Tunstall-Pedoe, H., Crombie, I. K. \& Tavendale, R. (1989). Concomitants of excess coronary deaths - major risk factor and lifestyle findings from 10359 men and women in the Scottish Heart Health Study. Scottish Medical Journal 34, 530 555.

SPSS $^{\times}$(1986). Users' Guide, 2nd ed. Chicago: Statistical Package for Social Sciences Inc.

Thomson, M., Fulton, M., Wood, D. A., Brown, S., Elton, R. A., Birtwistle, A. \& Oliver, M. F. (1985). A comparison of the nutrient intake of some Scotsmen with dictary recommendations. Human Nutrition: Applied Nutrition 39A, 443455.

Tunstall-Pedoe, H., Smith, W. C. S. \& Crombie, I. K. (1986). Levels and trends of coronary heart disease mortality in Scotland compared with some other countries. Health Bulletin 44, 153-161.

Tunstall-Pedoe, H., Smith, W. C. S., Crombie, I. K. \& Tavendale, R. (1989). Coronary risk factors and lifestyle variation across Scotland. Results from the Scottish Heart Health Study. Scottish Medical Journal 34, 556-560.

Uemura, K. \& Pisa, Z. (1988). Trends in cardiovascular disease mortality in industrialised countries since 1950. World Health Statistics Quarterly 41, 155-178.

Whichelow, M. J. (1989). Choice of spread by a random sample of the British population. European Journal of Clinical Nutrition 43, 1 -10.

Willett, W. C., Sampson, L., Stampfer, M. J., Rosner, B., Bain, C., Witschi, J., Hennekens, C. H. \& Speizer, F. E. (1985). Reproducibility and validity of a semi-quantitative food-frequency questionnaire. American Journal of Epidemiology 122, 51-56.

Yano, K., Rhoads, G. G., Kagan, A. \& Tillotson, J. (1978). Dietary intake and the risk of coronary heart disease in Japanese men living in Hawaii. American Journal of Clinical Nutrition 31, 1270-1279.

Yarnell, J. W. G., Fehily, A. M., Milbank, J. E., Sweetnam, P. M. \& Walker, C. L. (1983). A short dietary questionnaire for use in an epidemiological survey: comparison with weighed dietary records. Human Nutrition Applied Nutrition 37A, 103-112. 